\title{
A Study on the Soundness of Parent Rocks in Sri Lanka
}

\author{
Ude S Jayawardena* \\ Department of Civil Engineering, University of Peradeniya, Peradeniya, Sri Lanka
}

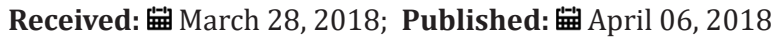

*Corresponding author: Ude S Jayawardena, Department of Civil Engineering, University of Peradeniya, Peradeniya, Sri Lanka, Email: udesja@gmail.com

\begin{abstract}
Studies on the engineering properties of different rock types provide a prior knowledge on the quality of such rock types as well as potential locations of suitable sources for the industry. The property "soundness" of a material measures the tendency to split into pieces similar to physical weathering during expansion and contraction processes within it. This soundness varies according to the type of minerals in a rock and its' origin. If rocks are using for aggregates for concrete or other applications the estimation of their soundness is necessary. With the aim of that, fresh rock samples of different rock types were collected from quarries and exposed rocks in different locali-ties in Sri Lanka to study the variation of soundness property in different rock aggregates. Samples were tested in the geotechnical engineering laboratory using sodium sulfate solution according to the Standard Method ASTM C88-99a. The rock types were Chranockite/charnockitic gneiss, garnet/hornblende/biotite gneiss, Microcline/Granitic gneiss, Garnet/biotite gneiss, Marble, Hornblende biotite gneiss, Quartzite, pegmatite, pink granite and Miocene limestone. Accordingly charnockite/ charnockitic gneiss shows the lowest loss of weight percentage as the highly sound rock for aggregates. Miocene limestone is the highly unfavorable rock.
\end{abstract}

Keywords: Soundness; Rock types; Aggregates; Constructions; Civil engineering

\section{Introduction}

The rocks have been classified as igneous, sedimentary and metamorphic according to their origin, texture and mineralogy. This classification is not valid for engineering science because rock is another material. Under the civil engineering category "a rock is a hard, consolidated and load bearing material and it cannot be excavated by manual methods". Hence rocks have been classified according to their properties for engineering purposes such as tunnels, underground openings, dam foundations etc. As far as Sri Lankan rocks are concerned, there are no (or very limited) published data to use as literature reviews. A classification of the various engineering properties of Sri Lankan rocks is therefore a necessity because it gives prior knowledge of these properties by identifying the type of rocks in any site. In order to prepare such a classification and provide more detailed literature of Sri Lankan rocks the author carried out a program of research to determine the engineering properties of those. The results of a part of this research have been published and now it is available for reference
$[1,2]$. It highlights the values of different engineering properties of Sri Lankan rocks and inter-relationships among them.

The quality of construction works in Civil Engineering largely depends on the properties of materials. The properties of rock aggregates depend upon the natural condition of different rock types. Therefore studies on the engineering properties of different rock types provide a prior knowledge on the quality of such rock types as well as potential locations of suitable sources for the industry. The property "soundness" of a material measures the tendency to split into pieces similar to physical weathering during expansion and contraction processes within it. This soundness varies according to the type of minerals in a rock and its' origin. The soundness of rocks should be found before use those as aggregates for concrete, as rip rap materials and as materials for protection the coastal zones, or as foundation rock especially for dam sites, harbors and marine structures. 
Soundness tests for fine aggregates were carried out using crusher dusts [3]. In this investigation the laboratory tests were limited for the coarse aggregates. The objective of this study is to classify different rock types found in Sri Lanka on the basis of their soundness and recommend the suitable rock types as aggregates for the construction industry.

\section{General Geography and Geology of Sri Lanka}

Sri Lanka is an Island in the Indian Ocean. The Island of Sri Lanka lies between latitudes 50 and 100 North and longitudes 790 and 820 East. It is situated $32 \mathrm{~km}$ east of the southern tip of India separated by Palk Strait and the Gulf of Mannar and 880 $\mathrm{km}$ north of the Equator. The total land area measures 65,610 square kilometres. Physio-graphically Sri Lanka consists as a central mountainous mass or central highland surrounded by a low, flat plain on all sides and extending to the sea [4]. Sri Lanka is considered to have a humid tropical climate. The mean annual rainfall for the Island is $2030 \mathrm{~mm}$. The temperature in the country generally lies between $140 \mathrm{C}$ and $320 \mathrm{C}$. On the basis of rainfall, the dryness and topography, Sri Lanka can be divided into three climatic zones namely the Dry Zone (rainfall less than $2000 \mathrm{~mm}$ ), the Intermediate Zone (rainfall between $2000 \mathrm{~mm}$ to $3000 \mathrm{~mm}$ ) and the Wet Zone (rainfall above $3000 \mathrm{~m}$ ) [5].

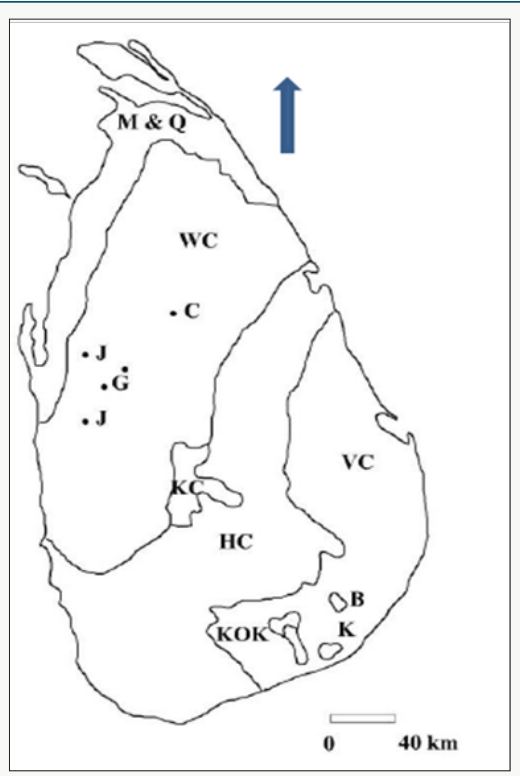

Figure 1: Subdivisions of the geology of Sri Lanka.

Precambrian Rocks: HC: Highland Complex; VC: Vijayan Complex; WC: Wanni Complex; KC: Kadugannawa Complex; B,K,KOK: Buttala Kataragama Complex

Sedimentary Rocks: J: Jurassic Rocks; M \& Q: Miocene and Quaternary Rocks

Intrusive Rocks: G: Granites; C: Carbonatite

Geologically nine tenth of Sri Lanka is made up of high grade metamorphic rocks of Precambrian age i.e., older than 570 million years, belonging to one of the ancient and stable part of the earth's crust, called the South Indian Shield. The remaining rocks are sedimentary rocks of predominantly Miocene age in the north-west (and very few places of south east) with some Jurassic sediments preserved in small faulted basins. There are recent sedimentary formations, identified as Pleistocene Deposits in a few locations. Intruding the metamorphic rocks of Sri Lanka are some granites, dolerites, pegmatites, quartz veins and a carbonatite [6]. Charnockitic gneiss or Charnockitic, quartzite, marble, dolomite, granulite, migmatite, gneisses (garnet sillimanite graphite gneiss, hornblende biotite gneiss, biotite gneiss, calc gneiss, cordierite gneiss, wollastonite-scapolite gneiss and granitic gneiss) and amphibolites are the common Precambrian metamorphic rocks in Sri Lanka. The widely distributed rocks within the country are charnockite, hornblende biotite gneiss, biotite gneiss, migmatite and granitic gneiss. Most of these metamorphic rocks are very hard and strong (Figure 1).

In most of places in the country the bedrocks are overlained by residual soils, weathered rocks, alluvial deposits or colluvial deposits. But there are many exposed rocks available for the quarrying industry in the mountain areas as well as low level flat terrains in Sri Lanka. Industrial rocks and minerals such as limestone, marble, dolomite, apatite, graphite, mica, feldspar and quartz are used for lime and other different industries as well as for export. Fresh outcrops of the other regional bedrocks are used in the construction industry. Metamorphic rocks such as gneisses, charnockite, migmatite, granulites, amphibolite and igneous origin granites are used for this industry. However the weathered rocks of those are not used for concrete or cement mixed constructions.

\section{Method of Study}

\section{Sample collection}

Fresh rock samples of different rock types were collected from quarries and exposed rocks in different localities in the Island. The metamorphic rock types are namely chranockite/charnockitic gneiss, charnockitic garnet/hornblende/biotite gneiss, quartzofeldspathic gneiss, microcline/granitic gneiss, garnet/biotite gneiss, horn-blende biotite gneiss, marble, quartzite and amphibolite. Pegmatite and pink granite the names of two intrusive rocks and Miocene limestone was the only sedimentary rock. Total samples collected for the experiments were 60 .

\section{Laboratory experiment}

Rubble size samples were collected from each location. Sample preparation and laboratory experiment for soundness test (coarse aggregates) was carried out for all samples separately in the geotechnical engineering laboratory. Each sample was sizes for the experiments as $63-50 \mathrm{~mm}, 50-37.5 \mathrm{~mm}, 37.5-25 \mathrm{~mm}, 25-19 \mathrm{~mm}$, $19-12.5 \mathrm{~mm}, 12.5-9.5 \mathrm{~mm}$ and $9.5-4.75 \mathrm{~mm}$. Total weight for one experiment was approximately $8,500 \mathrm{~g}$. Sodium sulfate was used to prepare the recommended solution according to the Standard Method ASTM C88-99a [1]. It takes sixteen days for one test (sample from one rock type). After the separation of broken fine particles 
using the suggested sieves, the weight loss were calculated for each fraction and found the total weight loss from the original weight as a percentage.

\section{Result and Discussion}

Previous studies on the engineering properties of rocks indicate that charnockite/charnockitic gneiss is the best and strongest rock for any civil engineering work in Sri Lanka. Quartzite is highly fractured and therefore it is highly permeable and porous, and weakest metamorphic rock. Due to the reaction effect with water marble rock also may be unfavorable for some works. All other metamorphic rocks are between these two extremes [2]. Tests carried out for two intrusive rocks also showed a wide variation among engineering properties. Pink granite is a hard, strong and uniform rock, and pegmatite is a highly fractured weak rock [7]. Miocene limestone, widely distributed sedimentary rock in Sri Lanka is a highly porous and permeable rock and not a strong rock. But some highly consolidated and compacted parts are strong [8].

The previous soundness test results for fine aggregates of different rock types were obtained using crusher dusts. The crusher dust is considered as a by-product of a crusher plant and separated from the main course aggregates by the crusher plant itself for concrete works. Crusher dust were obtained from all rock types except marble, dolomite, quartzite, pegmatite and Miocene limestone which are generally not used as construction materials in the industry. The results indicated that the soundness value (loss of weight percentage from the original) was more than $10 \%$ in all samples and varies between $10 \%$ and $15 \%$. . The soundness of both fine and coarse aggregates less than $10 \%$ loss is considered as a good material for concretes works. According to the test result fine aggregates from the crusher dusts are not suitable for concrete [3].

The results of the present study are also showing a wide range of soundness property. Table 1 shows charnockite/charnockitic gneiss is the highly sound and durable rock and quartzite is the weakest rock. Soundness of all other rocks occurs between these two extremes. Except marble all other rocks are gneiss with alternative mineral bands. These highly anisotropic rocks show a wide range of soundness.

Table 1: Results of laboratory tests for soundness of different rock types in Sri Lanka.

\begin{tabular}{|c|c|c|}
\hline Rock Type & $\begin{array}{c}\text { Soundness Value/or } \\
\text { Range of Values \% }\end{array}$ & $\begin{array}{c}\text { Number of Samples } \\
\text { Tested }\end{array}$ \\
\hline \multicolumn{3}{|c|}{ Metamorphic Rocks } \\
\hline $\begin{array}{c}\text { Chranockite/ } \\
\text { Charnockitic gneiss }\end{array}$ & $0.24-1.89$ & 27 \\
\hline $\begin{array}{c}\text { Charnockitic garnet/ } \\
\text { hornblende/ biotite } \\
\text { gneiss }\end{array}$ & $0.34-2.820$ & 7 \\
\hline Amphibolite & 0.39 & 3 \\
\hline $\begin{array}{c}\text { Microcline/Granitic } \\
\text { gneiss }\end{array}$ & $0.47-1.1$ & 1 \\
\hline
\end{tabular}

\begin{tabular}{|c|c|c|}
\hline Garnet/biotite gneiss & $2.29-9.5$ & 5 \\
\hline $\begin{array}{c}\text { Quartzofeldspathic } \\
\text { gneiss }\end{array}$ & $2.34-3.37$ & 3 \\
\hline Marble & $2.5-5.2$ & 3 \\
\hline $\begin{array}{c}\text { Hornblende biotite } \\
\text { gneiss/migmatite }\end{array}$ & $3.5-6.5$ & 3 \\
\hline Quartzite & $5.0-6.88$ & 3 \\
\hline \multicolumn{2}{|c|}{ Intrusive Rocks } \\
\hline pink granite & 0.75 & 1 \\
\hline pegmatite & 3.79 & 1 \\
\hline \multicolumn{2}{|c|}{ Sedimentary Rocks } \\
\hline Miocene limestone & $25-30$ & 3 \\
\hline
\end{tabular}

Accordingly charnockite/charnockitic gneiss is the highly suitable rock and Miocene limestone is the highly unfavorable rock on the basis of soundness property among Sri Lankan rocks. The soundness limits depends on the type of the concrete or the type of application. Generally the soundness (weight percentage loss) less than $10 \%$ are considered as a suitable material for some selected civil engineering works. Even though the fine aggregates are not suitable for concrete works [3] the course aggregates from fresh crystalline rocks (metamorphic and igneous) can be used for different civil engineering applications.

For some rock types the number of samples collected were not sufficient. This is very time consuming test and therefore difficult to do more tests with limited re-sources and space in the laboratory.

\section{Conclusion}

Except Miocene limestone the soundness value of all other rocks (coarse aggregates) is generally lies within the acceptable range. Charnockite/charnockitic gneiss is the best sound rock. Miocene limestone is highly unsuitable rock. Intrusive rocks and all other metamorphic rocks are generally suitable for the selected applications.

\section{References}

1. (1999) American Society for Testing and Materials (ASTM), Standard test for soundness of aggregates by use of sodium sulfate or magnesium sulfate, Designation C88-99a, ASTM International, West Conshohocken, USA, p. 41-45.

2. Jayawardena U de S (2009) Engineering properties of Sri Lankan rocks, Part I, Digital teleprints (Pvt) ltd, Kandy, Sri Lanka, pp. 156.

3. Jayawardena U de S (2012) A study on the soundness of crusher dust from different quarries in Sri Lanka, $34^{\text {th }}$ IGC, Brisbane, Australia, pp. 1260.

4. Vitanage PW (1970) A study of the geomorphology and morph tectonics of Ceylon, Proceedings of second seminar on geological prospecting methods and techniques, New York, USA, pp. 391-405.

5. Walker RC (1962) The hydrometeorology of Ceylon Part 1, Canada Colombo plan project, Government press, Ceylon, Sri Lanka.

6. Cooray PG (1984) An introduction to the geology of Sri Lanka (2 $\left.2^{\text {nd }} E d n\right)$; Dept of National Museums, Govt Press, Colombo, pp. 340. 
7. Jayawardena U de S (2008) The variation in aggregate impact values in different rock types of Sri Lanka. Geo Spectrum Interface 3(1): 27-29.
8. Jayawardena U de S (2016) Laboratory studies of Miocene limestone for the use of construction industry in Sri Lanka. Copernicus Publications, Germany.

\section{(c) (i) \\ This work is licensed under Creative Commons Attribution 4.0 License}

To Submit Your Article Click Here:

Submit Article

DOI: 10.32474/TCEIA.2018.01.000125

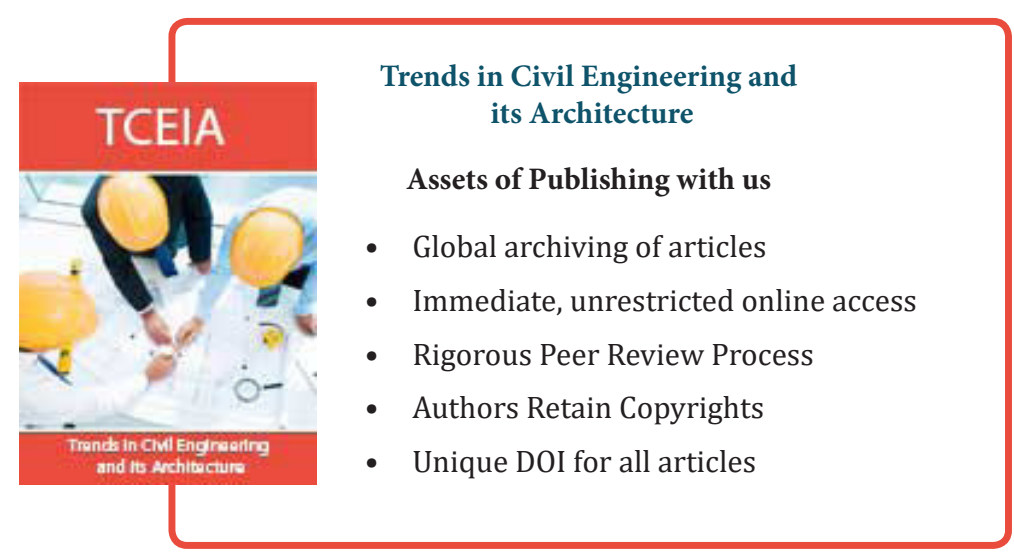

